\title{
Correction: Short-term variability of biomarkers of proteinase activity in patients with emphysema associated with type $\mathbf{Z}$ alpha- I-antitrypsin deficiency
} Jan Stolk*1, Barbara Veldhuisen ${ }^{2}$, Laura Annovazzi ${ }^{3}$, Chiara Zanone ${ }^{3}$, Elly M Versteeg ${ }^{5}$, Toine $\mathrm{H}_{\text {van Kuppevelt }}^{5}$, Jo HM Berden ${ }^{6}$, Willem Nieuwenhuizen ${ }^{7}$, Paolo Iadarola ${ }^{3}$ and Maurizio Luisetti ${ }^{4}$

Address: ${ }^{1}$ Department of Pulmonology, Leiden University Medical Center, Leiden, The Netherlands, ${ }^{2}$ Department of Medical Statistics, Leiden University Medical Center, Leiden, The Netherlands, ${ }^{3}$ Laboratory of Capillary Electrophoresis, Department of Biochemistry, University of Pavia, Italy, ${ }^{4}$ Laboratory of Biochemistry and Genetics, Department of Respiratory Disease, IRCCS San Matteo Hospital, Pavia, Italy, ${ }^{5}$ Department of Biochemistry, 194, University Medical Center, NCMLS Nijmegen, The Netherlands, ${ }^{6}$ Department of Nephrology, Radboud University Nijmegen Medical Center, Nijmegen, The Netherlands and 7TNO-Prevention and Health, Gaubius Laboratory, Leiden, The Netherlands

Email: Jan Stolk* - j.stolk.long@lumc.nl; Barbara Veldhuisen - b.veldhuisen@lumc.nl; Laura Annovazzi - lannova@unipv.it; Chiara Zanone - czanone@unipv.it; Elly M Versteeg - e.versteeg@ncmls.kun.nl; Toine H van Kuppevelt - a.vankuppevelt@ncmls.kun.nl; Jo HM Berden - j.berden@nier.umcn.nl; Willem Nieuwenhuizen -w.nieuwenhuizen@pg.tno.nl; Paolo Iadarola - piadarol@unipv.it; Maurizio Luisetti - m.luisetti@smatteo.pv.it

* Corresponding author

Published: 03 February 2006

Respiratory Research 2006, 7:20 doi:10.1 186/1465-9921-7-20
Received: 16 January 2006

Accepted: 03 February 2006

This article is available from: http://respiratory-research.com/content/7///20

(c) 2006 Stolk et al; licensee BioMed Central Ltd.

This is an Open Access article distributed under the terms of the Creative Commons Attribution License (http://creativecommons.org/licenses/by/2.0), which permits unrestricted use, distribution, and reproduction in any medium, provided the original work is properly cited.

\begin{abstract} pevelt TH, Nieuwenhuizen W, ladarola P, Luisetti M: Short-term variability of biomarkers of proteinase activity in patients with emphysema associated with type $Z$ alpha- I-antitrypsin deficiency. Respiratory Research 2005, 6:47. (3I May 2005)
\end{abstract}

After the publication of this work [I], we became aware of the fact that one author was missing on the author list. Dr Jo.H.M. Berden contributed the JM403 antibody and advised on the methodology for the ELISA for JM403. He also contributed to the text of the manuscript.

Apart from this correction concerning the authorship, the methods and interpretation of the data, the results reported in our publication and the conclusions are absolutely correct.

We apologize for the inconvenience that this inaccuracy may have caused.

\section{References}

I. Stolk J, Veldhuisen B, Annovazzi L, Zanone C, Versteeg EM, van Kup- 